\title{
The Impact of Residential Engineering Summer Academies on Middle and High School Students, (RTP-Diversity Paper)
}

\section{Dr. Vemitra M White, NASA Marshall \& Stennis Space Flight Centers/ Texas State University}

Dr. Vemitra White, a native of Crawford, Mississippi, graduated with her Ph.D. in 2016 from Mississippi State University in Instructional Systems and Workforce Development. She is currently a STEM Education Specialist for NASA Marshall Space Flight Center and NASA Stennis Space Center in Alabama and Mississippi respectively. Also, Vemitra is an Assistant Professor for the LBJ Institute for STEM Education and Research at Texas State University. She is very passionate about helping students matriculate through the STEM pipeline and enjoys developing programs that help students build their self-efficacy in STEM. Her areas of specialization are: teacher and student professional development, engineering education, project management, K-12 and university collaborator, workforce readiness, and STEM engagement/preparation.

Vemitra is a member of the Columbus Lowndes County Alumnae Chapter of Delta Sigma Theta Sorority, Inc., the recent award recipient of the 2019 Zacharias Distinguished Staff Award , the 2019 Bagley College of Engineering Service Award, and a newly elected executive committee member of the Pre-College Engineering Education Division, member of Phi Theta Kappa, Women's Basketball Collegiate Association, and Mississippi Educators Association. Her active participation in these organizations reveals her passion in helping others succeed. Vemitra is also a former collegiate basketball player where she played 2 years of women's basketball at Bevill State Community College in Fayette AL and her last 2 years at the University of West Georgia in Carrollton GA. She was a 4 year Academic All American.

\section{Dr. Debra Prince, Mississippi State University}

Debra Lindsey Prince earned her Ph.D. in Curriculum and Instruction from Mississippi State University in 2000 and currently serves as an associate professor in the Department of Leadership and Foundations. Her research interests are focused on poverty and the well-being of children and program evaluation.

\section{Dr. Jamel Hill Alexander, DoD}

Jamel Alexander received his Ph.D. in Mechanical Engineering from Mississippi State University. Prior to that, he received a Bachelor's in Physics from Xavier University of Louisiana; two Masters Degrees, one in Applied Physics from the University of New Orleans and the other in Mechanical Engineering from Mississippi State University. Dr. Alexander was the recipient of an NSF Fellowship, two GEM fellowships, and the 2016 NSBE Mike Shinn Member of the Year Award. Dr. Alexander's research includes multi-functional composites for extreme environments, multi-scale material modeling, STEAM Education, mentoring, and leadership. 


\title{
The Impact of Residential Engineering Summer Academies on Middle and High School Students (RTP-Diversity Paper)
}

\begin{abstract}
Mississippi ranks 48th in U.S. education and 47th in the production of technical staff. To address this issue, Mississippi State University's Bagley College of Engineering has developed and implemented two week-long residential summer academies for students in Grade 5 to Grade 9 to increase their engineering readiness, transferable technical skills, creativity and interest in the pursuit of engineering careers. The two academies used mini-lectures and team-oriented handson projects to engage 43 student participants in different engineering disciplines and their design processes. College staff placed student participants in either the Batmen Academy or Wonder Women Academy based on their gender. Researchers gave each student participant a Likert Scale survey to test their expectations and experience. The surveys provided insight into students' knowledge of various engineering disciplines, their interests to pursue engineering careers, their interests to take more math and science high school courses post completion of the academies, and their perception of the college environment. Further research assessed the differences in student perceptions towards pursuing an engineering degree by grade level, race, and gender post taking part in a week-long residential academy. Results show that majority of the participants' interests and knowledge of engineering increased because of taking part in the week-long academies. More boys $(84.3 \%)$ planned to take more math and science courses in high school than girls $(60 \%)$ post completing the academies. Also, highlighted in the findings were the representations of groups who are traditionally under-represented in the fields of engineering. The academy tailored for girls were very successful in recruiting African American students. Overall, the week-long academies and instructors on the university campus were effective in increasing student perceptions and experiences in engineering.
\end{abstract}

\section{introduction}

There is currently a demand in the United States for the development of skilled K-12 and post-secondary students with transferable technical skills, a knack for scientific exploration, and the ability to drive innovation through engineering design processes [1]. Scientific exploration and engineering education enable students to develop 6C skills (critical thinking, collaboration, communication, creativity, citizenship, and character) vital to problem-solving and growth of the United States economy [2]. To help students become qualified, many institutions have offered STEM pipeline programs at the middle and high school levels to build equity and encourage girls to consider STEM careers [3].

Several studies have found that middle-school students' participation in activities plays an important role in their self-development and formation of values [4][5][6]. Further research has shown that more exposure to a variety of STEM opportunities is likely to have a long-term impact on individuals and the overall STEM education community [7], and students who express interests in STEM by Grade 8 are three times more likely to pursue STEM degrees [8]. In 2015, Hammack et al. found that the attitudes of middle school participants towards engineering significantly increased post participating in a four-day long engineering camp [9]. The results of an informal week-long STEM camp at the University of Kentucky's Engineering School 
indicated that there was an overall increase in students' interest in STEM content and STEM fields as a career, and that students found hands-on sessions fun and engaging [10].

Compared to boys, attitudes towards STEM subjects for middle-school girls are becoming more negative between the seventh and ninth grades and are declining at a faster pace [11]. The current gender gap in girls' attitudes and interests most likely affects their performance in the STEM study and their lifestyle choices associated with important life phases [12]. In terms of career participation, women are less interested in STEM subjects and occupations than men [13]. Post a 2017 five-day all girls STEM camp at West Virginia Institute of Technology, 81\% (26/32) of the students indicated that their interests to pursue STEM careers increased [14]. Following a one-week long STEM program at Texas A\&M University-Kingsville, girls showed a $65 \%$ interest in pursuing an Engineering degree which demonstrates the effectiveness of the summer camp [15]. The literature review provided a good basis for implementing two engineering academies, one for boys and the other for girls in grades 5-9.

\section{camp background}

To increase participants' knowledge and interest in STEM fields and to increase their likelihood to pursue STEM careers, Mississippi State University's Bagley College of Engineering K-12 Outreach Office implemented two week-long residential academies. The two, week long academies catered to students in grades 5-9. The Batmen Academy provided hands on activities that represented eight different fields of engineering (mechanical, civil, chemical, biomedical, electrical, computer science, industrial, and aerospace). Activities included but not limited to:

1. Civil Engineering (Balsa Wood Bridge)

2. Electrical Engineering (Solar Rover Robot Activity)

3. Aerospace Engineering (Mars Robot Build)

4. Computer Engineering (Robotic Coding)

5. Biomedical Engineering (Pill Coating Activity)

6. Chemical Engineering (Bath Bomb Activity)

7. Mechanical Engineering (Roller Coaster Activity)

8. Industrial Engineering (Cookie Design/Manufacturing Activity)

The Wonder Women Academy were taught the same concepts from the eight different engineering disciplines; however, the girls were taught by a female engineer from industry along with female engineering students. The girls also did extracurricular activities such as face masks painting and spa treatments.

\section{methods}

The findings of this paper were generated from a Likert-scale survey that was completed by the summer academies participants post their participation in the week-long residential academies in July of 2018. The survey was designed to assess participants' perceptions of the academies in terms of their enjoyment of the academy and the benefit of their attendance. The survey had two sections in addition to two demographic items (grade and ethnicity). The first section included six Likert-scale items (Strongly Agree to Strongly Disagree) designed to determine the participants' perceptions of how their attendance at the academy benefitted them. The second section included seven, 3-point, Likert-scale items (Yes, very much; A little; and Not at all). The survey responses yielded a $100 \%$ response rate. 


\section{summer academies participants}

According to the surveys submitted, a small percentage (20\%) of the Wonder Women Academy participants were in elementary school (Grades 5 and 6), 65\% were in middle school (Grades 7 and 8) and the remaining percentage (15\%) were in high school (Grade 9). Grade level data recorded for the Batmen Academy was incomplete as only 17 of the 23 participants completed the grade level survey item. However, based on the 17 responses, the majority $(82.3 \%)$ of the participants were in middle school (Grades 7 and 8) and the remaining $17.7 \%$ were in elementary school (Grades 5 and 6). The data recorded did not list any high school students for the Batmen Academy. Tables 1 and 2 display the grade level data for the Wonder Women and Batmen Academies respectively.

Table 1: Grade Level of Wonder Women Academy Participants

\begin{tabular}{cccc}
\hline \multicolumn{3}{c}{ Grade Level Statistics for Wonder Women } \\
\hline \multirow{4}{*}{ Grade } & 5 & Frequency & Percent \\
& 6 & 2 & 10 \\
& 7 & 2 & 10 \\
& 8 & 8 & 40 \\
9 & 5 & 25 \\
& Total & 3 & 15 \\
& & 20 & 100 \\
\hline
\end{tabular}

Table 2: Grade Level of Batmen Academy Participants

\begin{tabular}{crr}
\hline \multicolumn{3}{c}{ Grade Level Statistics for Batmen } \\
\hline \multirow{3}{*}{ Grade } & Frequency & Percent \\
5 & 1 & 5.9 \\
6 & 2 & 11.8 \\
7 & 9 & 52.9 \\
8 & 5 & 29.4 \\
Total & 17 & 100 \\
Missing System & 6 & \\
Total & 23 & \\
\hline
\end{tabular}

The only other demographic data collected was that of ethnicity. In the fields of engineering, ethnicity is an important variable to examine due to the paucity of diversity found in the field. A review of the literature revealed that both women and African Americans are underrepresented in the fields of STEM in general and engineering specifically. While the Wonder Women Academy was designed to address the under-representation of women in the engineering workforce, the variable of ethnicity was not specifically targeted. In fact, African Americans represented the largest percentage of participants of the Wonder Women Academy with $70 \%$ of participants being African American, which addresses the need for more African American women in engineering careers. The largest percentage of participants for the Batmen 
Academy were Caucasian (65.0\%), but African Americans were well represented at 30.0\%. Tables 3 and 4 display data for the ethnicity of the participants of the two academies.

Table 3: Ethnicity of Wonder Women Academy Participants

\begin{tabular}{lrr}
\hline \multicolumn{3}{c}{$\begin{array}{c}\text { Ethnicity of Wonder Women } \\
\text { Participants }\end{array}$} \\
\hline & Frequency & Valid \\
& Percent \\
African American & 14 & 70.0 \\
Caucasian & 5 & 25.0 \\
Hispanic & 1 & 5.0 \\
& & 100 \\
Total & 20 & \\
\hline
\end{tabular}

Table 4: Ethnicity of Batmen Academy Participants

\begin{tabular}{lrr}
\hline \multicolumn{3}{c}{ Ethnicity of Batmen Participants } \\
\hline \multirow{3}{*}{ Frequency } & \multicolumn{1}{l}{ Valid } \\
& Percent \\
Black & 6 & 30.0 \\
White & 13 & 65.0 \\
Asian & 1 & 5.0 \\
Total & 20 & 100.0 \\
Missing System & 3 & \\
Total & 23 & \\
\hline
\end{tabular}

\section{overall academy experience}

The 43 participants of the Batmen and Wonder Women Academies completed the surveys as a means of assessing their perceptions of the academies. The first section of the survey consisted of six, 5-point Likert scale (ranging from Strongly Agree to Strongly Disagree) items and assessed participants' perceptions of academy benefits. The final part of this section consisted of one question used to assess participants' overall perceptions of their academy experience.

The results of the analysis of data for the first section of the survey revealed that, on average, the participants perceived the academy to be very beneficial. For the six positive statements on this section of the survey, the vast majority of respondents (ranging from $67.5 \%$ to $92.5 \%$ ) indicated that they either strongly agreed or agreed with the statement. For five of the six items in Table 5, the largest percent of participants strongly agreed with the statements provided. Only one item, Item 2 (At the Batmen/Wonder Women Academy, I learned about careers that I didn't know about before) had a higher percentage of participants agreeing with the statement than strongly agreeing with the statement. As displayed in Table 5, while "Not Sure" responses ranged from $5 \%$ to $27.5 \%$ across items, very few of the responses recorded can be interpreted as negative (Strongly Disagree and Disagree). The majority of responses recorded by the participants indicated that the academies were beneficial in terms of increasing 
their interests in and knowledge of engineering. The responses also indicated that the participants' experiences at the academies would have positive effects on their school behaviors and outcomes as they relate to math and science courses. Table 5 displays the items (statements) and the results of data analysis for the participants' responses to the items for the first section of the survey.

Table 5: Perceptions of Impact of the Batmen and Wonder Women Academies

\section{Perceptions of Impact of the Batmen and Wonder Women Academies}

Level of Agreement

Percentage (Number)

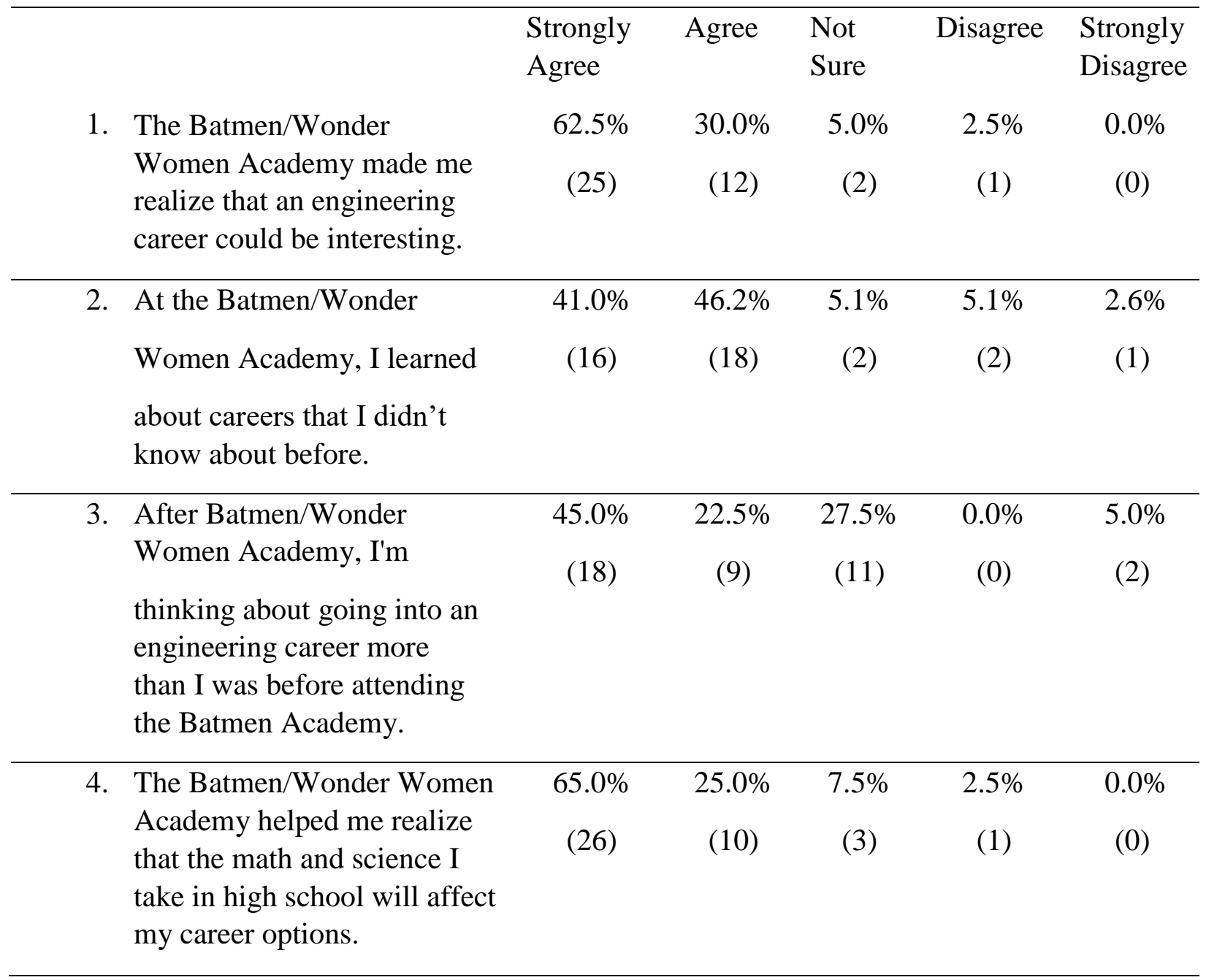




\begin{tabular}{llccccc}
\hline 5. I'm planning to take more & $46.2 \%$ & $25.6 \%$ & $20.5 \%$ & $5.1 \%$ & $2.6 \%$ \\
math and science courses in \\
high school than I was before \\
attending the \\
Batmen/Wonder Women \\
Academy.
\end{tabular}

In addition to the statements above the participants were asked to rate their overall academy experience on a scale of 1 to 5 with 1 being very bad and 5 being very good. For this item, all the participants except one recorded an overall rating for the academies. The mean score across all 42 surveys was 4.43 with a mode of 5 and a standard deviation of less than 1 . These scores indicate that on average, the participants thought the overall academy experience was good. Moreover, the mode score of 5 indicates that most of the participants thought the academies were very good. Table 6 displays the results of data analysis for this item of the survey.

Table 6: Overall Academy Experience

\begin{tabular}{lrr}
\hline \multicolumn{2}{c}{ Overall Academy Experience } \\
\hline Very Bad & 2 & 4.8 \\
Bad & 0 & 0.0 \\
O.K. & 1 & 2.4 \\
Good & 14 & 33.3 \\
Very Good & 25 & 59.5 \\
Total & 42 & 100.0 \\
System Missing & 1 & \\
Total & 43 & \\
\hline
\end{tabular}

The second section of the survey, consisting of seven Likert scale items and one multiple response item, gathered the participants' perceptions of their enjoyment of the academy and their reasons for attending the academy. For each Likert scale item, the participants had three choices for their response. The "Yes, very much" response is considered positive and the "A Little" response is considered somewhat neutral. The least favorable response and considered negative was the "Not at all" response.

Identical to the results of the analysis of data for the first section of the survey, the vast majority of participants recorded a positive response to each of the seven items. For each item, from $51.2 \%$ to $97.7 \%$ of the participants recorded the "Yes, very much" response. Very few, if any, of the participants selected the "Not at all" response. For five of the seven items, one participant selected the "Not at all" response. More specifically, examination of individual 
surveys revealed that all "Not at all" responses were recorded by three boys attending the Batmen Academy. While knowing that there were some participants who did not enjoy certain aspects of the academies is noteworthy, the negative perception(s) of these three individuals were certainly not the norm (outliers) nor indicative of most participants overall academy experience.

In fact, the finding that only five of the 301 total responses collected for this section of the survey were negative is quite admirable and indicates that less than $2 \%$ of responses were negative. However, there were three items (Did your attendance at the Batmen/Wonder Women Academy increase your interest in engineering?; Were you pleased with the housing that was provided for you at the Batmen/Wonder Women Academy?; and Were you pleased with the meals that were provided for you at the Batmen/Wonder Women Academy?) with significant percentages (ranging from $25.6 \%$ to $39.5 \%$ ) of participants recording "A Little" responses. As previously stated, the "A Little" response is considered somewhat neutral, not bad, but not positive. Table 7 displays the Likert scale items (statements) and the results of data analysis for the participants' responses for this section of the survey.

Table 7: Perceptions of Batmen and Wonder Women Academy Participants

Question
Response

Percentage (Number)

$\underline{\text { Yes, very much }}$

$88.4 \%$ Academy?

2. Was what you learned during the Batmen/Wonder Women Academy helpful to you?

3. Were the Batmen/Wonder Women Academy instructors helpful to you?

4. Did you learn exciting new things at the Batmen/Wonder Women Academy?

5. Did your attendance at the Batmen/Wonder Women Academy increase your interest in engineering?
$86.0 \%$

$97.7 \%$

$86.0 \%$

$72.1 \%$
A Little Not at all

$9.3 \% \quad 2.3 \%$

$11.6 \%$

$2.3 \%$

$2.3 \% \quad \mathbf{0 . 0}$

$11.6 \%$

$2.3 \%$

$25.6 \% \quad 2.3 \%$ 
6. Were you pleased with the housing that was provided for you at the

Batmen/Wonder Women Academy?

7. Were you pleased with the meals that were provided for you at the

Batmen/Wonder Women Academy?
$51.2 \%$

$60.5 \%$
$46.5 \%$

$2.3 \%$

(1)

$39.5 \% \quad 0.0 \%$

The multiple response item of the survey was used to determine reasons why the participants attended the Batmen and Wonder Women academies. The survey listed six reasons for attending the academy and participants were asked to check all the reasons why they attended the camp. The most common reason recorded for attending the academy was that the participants thought they would have fun (selected 40 times) followed by I thought I would learn something (selected 37 times) and wanting to learn more about Mississippi State University (selected 28 times). According to participants' responses, teacher's recommendation to attend the academy was the least common reason for attending. Only two participants indicated that their teacher told them to attend the camp. Table 8 displays the reasons provided for academy attendance and the number of times that reason was selected.

Table 8: Reasons for Batmen/Wonder Women Academy Attendance

\begin{tabular}{lc}
\hline \multicolumn{1}{c}{ Reason for Attendance } & $\begin{array}{c}\text { Number of Times } \\
\text { Selected }\end{array}$ \\
\hline I thought it would be fun. & 40 \\
I thought I would learn something. & 37 \\
My teacher told me to attend. & 2 \\
My friends were attending the Batmen/Wonder Women & 8 \\
Academy. & 9 \\
My parents made me attend the Batmen/Wonder Women \\
Academy.
\end{tabular}

results by academy

As a means of determining if there were any differences in the perceptions of the academies by the participants of the Wonder Women Academy and the Batmen Academy, the 
survey responses were examined and analyzed by academy. The analysis of Wonder Women Academy data revealed, similar results to the overall combined results, that the majority of participants found the academy to be both beneficial and enjoyable. Analysis of survey responses from Section 1 of the survey yielded very positive scores. In fact, for the six Likert scale items on this section of the survey, from $60 \%$ to $100 \%$ of the participants strongly agreed or agreed with the positive statements presented to them. Across all surveys and survey items, there were only six disagree or strongly disagree responses.

Data analysis of Section 2 from the survey also revealed very positive findings. Across all seven items on this section of the survey, none of the participants recorded a "Not at all" response and in most cases, very few "A Little" responses were recorded. However, on item 6 of this section, over half of the participants $(60 \%)$ recorded the "A Little" response when asked if they were pleased with the housing provided for them. Nevertheless, the overall results of the analysis of Wonder Women Academy data indicated that the participants were pleased with the academy. Tables 9 and 10 display the results of the analysis of data for Sections 1 and 2, respectively, of the Wonder Women Academy survey.

Table 9: Perceptions of Impact of the Wonder Women Academy

\section{Perceptions of Benefit of the Wonder Women Academy}

\section{Level of Agreement}

\begin{tabular}{|c|c|c|c|c|c|}
\hline & $\begin{array}{l}\text { Strongly } \\
\text { Agree }\end{array}$ & Agree & $\begin{array}{l}\text { Not } \\
\text { Sure }\end{array}$ & Disagree & $\begin{array}{l}\text { Strongly } \\
\text { Disagree }\end{array}$ \\
\hline $\begin{array}{l}\text { The Wonder Women Academy made } \\
\text { me realize that an engineering career } \\
\text { could be interesting. }\end{array}$ & $\begin{array}{c}15 \\
(75 \%)\end{array}$ & $\begin{array}{c}4 \\
(20 \%)\end{array}$ & $\begin{array}{c}1 \\
(5.0)\end{array}$ & $\begin{array}{c}0 \\
(0.0)\end{array}$ & $\begin{array}{c}0 \\
(0.0)\end{array}$ \\
\hline $\begin{array}{l}\text { At the Wonder Women Academy, I } \\
\text { learned about careers that I didn't } \\
\text { know about before. }\end{array}$ & $\begin{array}{c}8 \\
(40 \%)\end{array}$ & $\begin{array}{c}9 \\
(45 \%)\end{array}$ & $\begin{array}{c}1 \\
(5.0 \%)\end{array}$ & $\begin{array}{c}2 \\
(10.0 \%)\end{array}$ & $\begin{array}{c}0 \\
(0.0)\end{array}$ \\
\hline $\begin{array}{l}\text { After Wonder Women Academy, I'm } \\
\text { thinking about going into an } \\
\text { engineering career more than I was } \\
\text { before attending the Wonder Women } \\
\text { Academy. }\end{array}$ & $\begin{array}{c}8 \\
(40.0 \%)\end{array}$ & $\begin{array}{c}7 \\
(35.0 \%)\end{array}$ & $\begin{array}{c}4 \\
(20.0 \%)\end{array}$ & $\begin{array}{l}0 \\
(0)\end{array}$ & $\begin{array}{c}1 \\
(5.0)\end{array}$ \\
\hline $\begin{array}{l}\text { The Wonder Women Academy } \\
\text { helped me realize that the math and } \\
\text { science I take in high school will } \\
\text { affect my career options. }\end{array}$ & $\begin{array}{c}14 \\
(70.0 \%)\end{array}$ & $\begin{array}{c}6 \\
(30.0 \%)\end{array}$ & $\begin{array}{c}0 \\
(0.0)\end{array}$ & $\begin{array}{c}0 \\
(0.0)\end{array}$ & $\begin{array}{c}0 \\
(0.0)\end{array}$ \\
\hline
\end{tabular}




\begin{tabular}{|c|c|c|c|c|c|}
\hline $\begin{array}{l}\text { I'm planning to take more math and } \\
\text { science courses in high school than I } \\
\text { was before attending the Wonder } \\
\text { Women Academy. }\end{array}$ & $\begin{array}{c}6 \\
(30.0 \%)\end{array}$ & $\begin{array}{c}6 \\
(30.0 \%)\end{array}$ & $\begin{array}{c}6 \\
(30.0 \%)\end{array}$ & $\begin{array}{c}1 \\
(5.0 \%)\end{array}$ & $\begin{array}{c}1 \\
(5.0)\end{array}$ \\
\hline $\begin{array}{l}\text { I'm planning to work harder in my } \\
\text { math and science courses. }\end{array}$ & $\begin{array}{c}16 \\
(80.0 \%)\end{array}$ & $\begin{array}{c}2 \\
(10.0 \%)\end{array}$ & $\begin{array}{c}1 \\
(5.0 \%)\end{array}$ & $\begin{array}{c}0 \\
(0.0)\end{array}$ & $\begin{array}{c}1 \\
(5.0)\end{array}$ \\
\hline
\end{tabular}


Table 10: Perceptions of Enjoyment of Wonder Women Academy Participants

\begin{tabular}{|c|c|c|c|}
\hline \multirow[t]{2}{*}{ Question } & \multicolumn{3}{|c|}{ Response } \\
\hline & Yes, very much & A Little & $\frac{\text { Not at }}{\text { all }}$ \\
\hline Did you enjoy the Wonder Women Academy? & $\begin{array}{c}19 \\
(95.0 \%)\end{array}$ & $\begin{array}{c}1 \\
(5.0 \%)\end{array}$ & $\begin{array}{c}0 \\
(0.0 \%)\end{array}$ \\
\hline $\begin{array}{l}\text { Was what you learned during the Wonder } \\
\text { Women Academy helpful to you? }\end{array}$ & $\begin{array}{c}17 \\
(85.0 \%)\end{array}$ & $\begin{array}{c}3 \\
(15.0 \%)\end{array}$ & $\begin{array}{c}0 \\
(0.0 \%)\end{array}$ \\
\hline $\begin{array}{l}\text { Were the Wonder Women Academy instructors } \\
\text { helpful to you? }\end{array}$ & $\begin{array}{c}19 \\
(95.0 \%)\end{array}$ & $\begin{array}{c}1 \\
(5.0 \%)\end{array}$ & $\begin{array}{c}0 \\
(0.0 \%)\end{array}$ \\
\hline $\begin{array}{l}\text { Did you learn exciting new things at the Wonder } \\
\text { Women Academy? }\end{array}$ & $\begin{array}{c}18 \\
(90.0 \%)\end{array}$ & $\begin{array}{c}2 \\
(10.0 \%)\end{array}$ & $\begin{array}{c}0 \\
(0.0 \%)\end{array}$ \\
\hline $\begin{array}{l}\text { Did your attendance at the Wonder Women } \\
\text { Academy increase your interest in engineering? }\end{array}$ & $\begin{array}{c}14 \\
(70.0 \%)\end{array}$ & $\begin{array}{c}6 \\
(30.0 \%)\end{array}$ & $\begin{array}{c}0 \\
(0.0 \%)\end{array}$ \\
\hline $\begin{array}{l}\text { Were you pleased with the housing that was } \\
\text { provided for you at the Wonder Women } \\
\text { Academy? }\end{array}$ & $\begin{array}{c}8 \\
(40.0 \%)\end{array}$ & $\begin{array}{c}12 \\
(60.0 \%)\end{array}$ & $\begin{array}{c}0 \\
(0.0 \%)\end{array}$ \\
\hline $\begin{array}{l}\text { Were you pleased with the meals that were } \\
\text { provided for you at the Wonder Women } \\
\text { Academy? }\end{array}$ & $\begin{array}{c}15 \\
(75.0 \%)\end{array}$ & $\begin{array}{c}5 \\
(25.0 \%)\end{array}$ & $\begin{array}{c}0 \\
(0.0 \%)\end{array}$ \\
\hline
\end{tabular}

The responses recorded on the surveys of the Batmen Academy participants were very positive and similar to those recorded on the surveys of the Wonder Women participants. In fact, from $60-90 \%$ of all responses were strongly agree or agreed. Only five responses on 
Section 1 of the survey were responses where one participant either disagreed or strongly disagreed to the supplied statement. Table 11 displays the supplied statements and the analysis of the recorded responses for the surveys submitted by the participants of the Batmen Academy.

The responses recorded on section 2 of the survey for the Batmen participants were consistent with those recorded by the participants of the Wonder Women Academy. Of the 23 surveys submitted, 19 of the participants indicated that they enjoyed the Batmen Academy very much, three indicated that they enjoyed it a little, and one participant indicated that he did not enjoy the academy at all. This was the same participant who recorded all five of the disagree or strongly disagree statements. However, this participant agreed with the other 22 participants when asked if their instructors were helpful. For this item, all 23 participants recorded the "yes, very much" responses when asked if their instructors were helpful. Similar to the overall results and the results of the Wonder Women Academy survey analysis, the responses recorded by the Batmen Academy participants indicated that they enjoyed the academy and that the academy was beneficial to them. Table 12 displays the results of the analysis of data for section 2 of the survey.

Table 11: Perceptions of Impact of the Batmen Academy

\section{Perceptions of Impact of the Batmen Academy}

\begin{tabular}{|c|c|c|c|c|c|}
\hline & \multicolumn{5}{|c|}{ Level of Agreement } \\
\hline & $\begin{array}{l}\text { Strongly } \\
\text { Agree }\end{array}$ & Agree & $\begin{array}{l}\text { Not } \\
\text { Sure }\end{array}$ & Disagree & $\begin{array}{l}\text { Strongly } \\
\text { Disagree }\end{array}$ \\
\hline $\begin{array}{l}\text { The Batmen Academy made me } \\
\text { realize that an engineering career } \\
\text { could be interesting. }\end{array}$ & $\begin{array}{c}10 \\
(50.0 \%)\end{array}$ & $\begin{array}{c}8 \\
(40.0 \%)\end{array}$ & $\begin{array}{c}1 \\
(5.0 \%)\end{array}$ & $\begin{array}{c}1 \\
(5.0 \%)\end{array}$ & $\begin{array}{c}0 \\
(0.0 \%)\end{array}$ \\
\hline $\begin{array}{l}\text { At the Batmen Academy, I learned } \\
\text { about careers that I didn't know } \\
\text { about before. }\end{array}$ & $\begin{array}{c}8 \\
(42.1 \%)\end{array}$ & $\begin{array}{c}9 \\
(47.4 \%)\end{array}$ & $\begin{array}{c}1 \\
(5.3 \%)\end{array}$ & $\begin{array}{c}0 \\
(13.0 \%)\end{array}$ & $\begin{array}{c}1 \\
(5.3 \%)\end{array}$ \\
\hline $\begin{array}{l}\text { After Batmen Academy, I'm } \\
\text { thinking about going into an } \\
\text { engineering career more than I was } \\
\text { before attending the Batmen } \\
\text { Academy. }\end{array}$ & $\begin{array}{c}10 \\
(50.0 \%)\end{array}$ & $\begin{array}{c}2 \\
(10.0 \%)\end{array}$ & $\begin{array}{c}7 \\
(35.0 \%)\end{array}$ & $\begin{array}{c}0 \\
(0.0 \%)\end{array}$ & $\begin{array}{c}1 \\
(5.0 \%)\end{array}$ \\
\hline $\begin{array}{l}\text { The Batmen Academy helped me } \\
\text { realize that the math and science I } \\
\text { take in high school will affect my } \\
\text { career options. }\end{array}$ & $\begin{array}{c}12 \\
(60.0 \%)\end{array}$ & $\begin{array}{c}4 \\
(20.0 \%)\end{array}$ & $\begin{array}{c}3 \\
(15.0 \%)\end{array}$ & $\begin{array}{c}1 \\
(5.0 \%)\end{array}$ & $\begin{array}{c}0 \\
(0.0 \%)\end{array}$ \\
\hline
\end{tabular}




\begin{tabular}{lccccc}
\hline $\begin{array}{l}\text { I'm planning to take more math and } \\
\text { science courses in high school than I } \\
\text { was before attending the Batmen }\end{array}$ & $\begin{array}{l}12 \\
\text { Academy. }\end{array}$ & $\begin{array}{c}4 \\
(63.2 \%)\end{array}$ & $\begin{array}{c}21.1 \%) \\
(10.5 \%)\end{array}$ & $\begin{array}{c}1 \\
(5.3 \%)\end{array}$ & $(0.0 \%)$ \\
& & & & & \\
\hline $\begin{array}{l}\text { I'm planning to work harder in my } \\
\text { math and science courses. }\end{array}$ & 13 & 5 & 2 & 0 & 0 \\
& $(65.0 \%)$ & $(25.0 \%)$ & $(10.0 \%)$ & $(0.0 \%)$ & $(0.0 \%)$ \\
\hline
\end{tabular}

Table 12: Perceptions of Enjoyment of Batmen Academy Participants

Question

Was what you learned during the Batmen

Academy helpful to you?

Were the Batmen Academy instructors helpful to you?

Did you learn exciting new things at the Batmen Academy?

Did your attendance at the Batmen Academy increase your interest in engineering?

Were you pleased with the housing that was provided for you at the Batmen Academy?
Response

$\underline{\text { Not at }}$

$\underline{\text { Yes, very much A Little all }}$

19

3

$(82.6 \%)$

(13.0\%)

$(4.3 \%)$
19

(82.6\%)

17

(73.9\%)

23

$(100.0 \%)$

$(0.0 \%)$
1

(4.3\%)

0

$(0.0 \%)$

9

\section{3}

(13.0\%)

(4.3\%)

1

1

(21.7\%)

$\begin{array}{ccc}14 & 8 & 1 \\ (60.9 \%) & (34.8 \%) & (4.3 \%)\end{array}$


Were you pleased with the meals that were provided for you at the Batmen Academy?

11

$(47.8 \%)$
12

$(52.2 \%)$
0

$(0.0 \%)$

\section{conclusion}

The results of data analysis for all completed surveys indicated that the academies designed, developed, and provided by Mississippi State University Bagley College of Engineering were perceived to be not only enjoyable, but also beneficial to the participants. The results indicate that participants' interests in and knowledge of engineering increased because of their participation in the academies which agrees with the literature found by White et. al. (2017), Kager and Kager (2019), as well as Hargraves (2015). Also highlighted in the findings were the representations of groups who are traditionally under-represented in the fields of engineering. In addition, to the academy designed specifically for girls, the academies were very successful in recruiting African American students. Successful recruitment of minority students, namely girls and African Americans for programs such as the Wonder Women Academy and the Batmen Academy is one significant means of increasing diversity in the fields of engineering and STEM. Interestingly, when examining the perceptions of impact for the Batmen and Wonder Women Academies, the results showed that girls found engineering careers $25 \%$ more interesting which contradicts the work of LTO Brien et. al. (2017) and Wang (2018) for middle school girls. Instruction led by female industry engineers and female student engineers likely increased girl participants' interest to pursue engineering careers. Female engineering students and female industry representatives provided professional development sessions that focused on women in technical leadership roles and confidence building exercises. 


\section{References}

[1] V. M. White, J. H. Alexander, and D. Prince, "Mississippi BEST robotics: An analysis of impact and outcomes on student performance and perceptions towards earning STEM degrees," ASEE Annu. Conf. Expo. Conf. Proc., vol. 2017-June, 2017, doi: 10.18260/1-2-28674.

[2] C. Kagar and T. Kagar, "The Impact of Children' s Long -Term Participation in STEM Clubs on Their Attitudes towards STEM Subjects," no. March, 2019, doi: 10.21585/ijcses.v0i0.51.

[3] C. Demetry and S. Sontgerath, "A middle school engineering outreach program for girls yields STEM undergraduates," ASEE Annu. Conf. Expo. Conf. Proc., vol. 2017-June, 2017, doi: 10.18260/1-2--27481.

[4] N. Dasgupta and J. G. Stout, "Girls and Women in Science, Technology, Engineering, and Mathematics : STEMing the Tide and Broadening Participation in STEM Careers," 2014, doi: $10.1177 / 2372732214549471$.

[5] R. H. Hargraves, "Engineering Everyday Discovery Program : Motivating Middle School Chil- dren Interest in STEM Work In Progress - Everyday Engineering Discovery Program : Motivating Middle School Children Interest in STEM,” 2015.

[6] X. Kong, K. P. Dabney, and R. H. Tai, "The Association Between Science Summer Camps and Career Interest in International Journal of Science Education, Part B : Communication and Public Engagement The Association Between Science Summer Camps and Career Interest in Science and Engineering," no. February, 2013, doi: 10.1080/21548455.2012.760856.

[7] J. Wai, D. Lubinski, C. P. Benbow, and J. H. Steiger, "Accomplishment in Science, Technology, Engineering, and Mathematics ( STEM ) and Its Relation to STEM Educational Dose : A 25-Year Longitudinal Study," vol. 102, no. 4, pp. 860-871, 2010, doi: $10.1037 / \mathrm{a} 0019454$.

[8] President's Council of Advisors on Science and Technology (PCAST). (2010). Prepare and inspire : K-1 2 education in science, technology, engineering, and math ( S T E M ) for America's Future. White House Office of Science and Technology Polilcy (OSTP), Washington, DC. Retrieved from www.whitehouse.gov/administration/eop/ostp/pcast/docsreports.

[9] R. Hammack, T. A. Ivey, J. Utley, and K. A. High, "Effect of an Engineering Camp on Students 'Perceptions of Engineering and Technology and Technology," vol. 5, no. 2, 2015.

[10] M. J. Mohr-schroeder, D. L. Little, and D. C. Schroeder, "Developing Middle School Students 'Interests in STEM via Summer Learning Experiences : See Blue STEM Camp," pp. 291-301, 2012.

[11] L. T. O. Brien, A. Hitti, E. Shaffer, A. R. Van Camp, D. Henry, and P. N. Gilbert, "Improving Girls' Sense of Fit in Science : Increasing the Impact of Role Models," vol. 8, no. 3, pp. 301-309, 2017, doi: 10.1177/1948550616671997. 
[12] C. A. Hill and C. Corbett, Why So Few ?, no. May 2015. 2010.

[13] C. Wang, "miniGEMS 2018: A Mixed Methods Study Exploring the Impact of a STEAM and Programming Camp on Middle School Girls' STEM Attitudes miniGEMS 2018: A Mixed Methods Study Exploring the Impact of a STEAM and Programming Camp on Middle School Girls 'STEM Attitudes,” no. June, 2019.

[14] A. Naz and W. Virginia, "A Summer STEM Camp for Girls A Summer STEM Camp for Girls Virginia University Institute of Technology with Toyota Motor Manufacturing Virginia," 2012.

[15] M. Yilmaz, A. Texas, and M. U. Tamuk, "A Female-Only Camp for STEM Disciplines A Female-Only Camp for STEM Disciplines,” 2007. 